\title{
PENGATURAN INSOLVENCY TEST DALAM PENJATUHAN PUTUSAN PAILIT TERHADAP PERUSAHAAN*
}

\author{
Oleh \\ Luh ayu Maheswari Prabaningsih** \\ Made Nurmawati ${ }^{* * *}$ \\ Program Kekhususan Hukum Bisnis Fakultas Hukum Universitas \\ Udayana
}

\begin{abstract}
ABSTRAK
Tidak diterapkannya Insolvency Test menyebabkan banyaknya perusahaan di Indonesia yang bangkrut secara hukum, terutama PT (perseroan terbatas). Undang-undang Nomer 37 Tahun 2004 tentang Kepalitan dan Penundaan Kewajiban Pembayaran Utang (PKPU) hanya mengatur mengenai Insolvency, namun tidak mengatur lebih lanjut mengenai Insolvency Test dalam penetapan pailit pada Perseroan Terbatas (PT).Dengan dinyatakan pailitnya suatu Perseroan Terbatas (PT), maka harta kekayaan Perseroan Terbatas tersebut akan berada dalam sitaan umum dan Perseroan Terbatas akan kehilangan haknya untuk mengurus harta kekayaannya. Namun, akan lebih baik jika dalam Undang-Undang Nomer 37 Tahun 2004 Tentang UUK dan PKPU Insolvency Test dapat dimasukan dan disebutkan untuk memperjelas apakah suatu perusahaan dapat benar-benar disebut dalam keadaan solven atau tidak. Adapun permasalahanya adalah Urgency/pentingnya Insolvency Test dalam penjatuhan pailit pada perusahaan? Dan Bagaimana akibat

* Pengaturan Insolvency Test Dalam Penjatuhan Putusan Pailit Terhadap Perusahaan merupakan karya ilmiah diluar ringkasan skripsi.

${ }^{* *}$ Luh Ayu Maheswari Prabaningsih (1604552021) adalah Mahasiswa Bagian Hukum Bisnis Fakultas Hukum Universitas Udayana, Selaku penulis pertama, alamat : Jl Legian Gang Bedugul,Kuta, Korespondensi dengan penulis melalui email: ayumaheswari@yahoo.com

*** Made Nurmawati,SH.,MH. (NIP: 196203311987022001) adalah Dosen Bagian Hukum Tata Negara Fakultas Hukum Universitas Udayana, Alamat J1 Nuansa Udayana I Nomor 16 Perum Kori Nuansa Jimbaran.
\end{abstract}


hukumnya apabila perusahaan/Perseroan Terbatas (PT) dimohonkan insolvency test sebelum dinyatakan pailit? Dengan menggunakan metode penelitian normatif yaitu metode penelitian yang menggunakan aturan hukum, maupun doktrin-doktrin hukum untuk menjawab isu hukum yang dibahas. Tujuannya untuk mengetahui pentingnya Insolvency Test dalam penetapan pailit pada Perseroan Terbats (PT). Hasil dari penelitian ini adalah apabila diliat dari negara-negara lain jika di Indonesia mengatur mengenai Insolvency Test sebagai syarat untuk suatu perusahaan berbadan hukum tersebut dinyatakan pailit maka tidak banyak perusahaan berbadaan hukum yang masih dikatakan solven atau mampu membayar dinyatakan pailit oleh Pengadilan Niaga.

\title{
Kata Kunci : Insolvency Test; Perusahaan; Pailit
}

\begin{abstract}
The implementation of the Insolvency Test has caused many companies in Indonesia to be legally bankrupt, in this case, for example, incorporated companies, namely PT (limited liability company). The Law Number 37 of 2004 concerning Bankruptcy and Postponement of Debt Payment Obligations (PKPU) only regulates Insolvency, but does not regulate further on Insolvency Test in the bankruptcy of a Limited Liability Company (PT).The Law Number 37 of 2004 concerning Bankruptcy and Postponement of Debt Payment Obligations (PKPU) in its application doesn't specify whether in Indonesia Insolvency Test can determine whether a incorporated companies that is still in solvent can be declared bankrupt. By declaring bankruptcy of a Perseroan Terbatas $(P T)$, the assets of the Perseroan Terbatas (PT) will be in a public confiscation and the Perseroan Terbatas (PT) will lose its right to manage its assets. In Law Number 37 Year 2004 concerning UUK and $P K P U$, the Insolvency Test can be included and mentioned to clarify whether a company can actually be called a solvent or not. The problem is the Urgency / importance of Insolvency Test in the bankruptcy of the company? And what are the legal consequences of insolvency tests on companies that have been filed for bankruptcy? By using normative research methods, namely research methods that use the rule of law, as well as legal doctrines to answer legal issues discussed. The aim is to find out the importance of Insolvency Test in the determination of bankruptcy in the Limited Company (PT).The results of this study are
\end{abstract}


that if it is seen from other countries if in Indonesia regulates the Insolvency Test as a requirement for a legal entity companies to be declared bankrupt then not many legal companies are still said to be solvent or able to pay declared bankrupt by the Commercial Court.

\section{Keywords : Insolvency Test; Company; Bankrupt}

\section{PENDAhUluan}

\subsection{Latar Belakang}

Menurut Undang-Undang Nomer 37 Tahun 2004 tentang Kepilitan dan Penundaan Kewajiban Pembayaran Utang (PKPU) Pasal 1 angka 1 menyebutkan bahwa, Kepailitan merupakan sita umum atas harta kekayaan debitor pailit yang pengurusan dan pemberesannya dilakukan oleh kurator dibawah pengawasan hakim pengawas.Ketidakmampuan membayar debitor umumnya disebabkan karena kesulitan kondisi keuangan perusahaan / financial distress.

Tujuan dari penjatuhan pailit adalah demi perlindungan baik terhadap debitor pailit sendiri maupun terhadap kreditor. Perlindungan terhadap debitor yaitu dengan adanya putusan pailit, maka eksekusi yang tidak legal dapat dihindari bahkan dapat dihentikan. Sedangkan perlindangan bagi kreditor yang beraneka ragam dan akan menimbulkan suatu keadaan kacau (chaotic), maka dengan adanya putusan pailit,dapat menghindari dan menghentikan perbutan harta baik yang saling mendahului atau saling adu kekuatan. ${ }^{1}$

Dalam perkembangan kepailitan di Indonesia tenyata pengaturan mengenai Insolvency test dalam penjatuhan pailit terhadap perusahaan khususnya perusahaan berbadaan hukum belum di atur

1 Hadi Subhan,2009,Hukum Kepailitan: Prinsip,Norma, \& Praktik di Peradilan, Kencana, Jakarta, hal. 168-169. 
dalam UU No.37 Tahun 2004 tentang Kepilitan dan Penundaan Kewajiban Pembayaran Utang (PKPU). Pengertian Insolvency, menurut UU No.37 Tahun 2004 Pasal 57 ayat 1, merupakan tahap menentukan dimana debitor pailit dapat dikatakan masih dalam keadaan solven (mampu membayar) atau Insolven (tidak mampu membayar).Selain itu Insolvensi juga dikatakan sebagai ketidaksanggupan untuk memenuhi kewajiban finansial ketika jatuh waktu seperti layaknya dalam suatu perusahaan, atau kelebihan kewajiban dibandingkan asetnya dalam waktu tertentu. ${ }^{2}$ Jika debitor telah dinyatakan insolvensi,debitor sudah benar-benar pailit dan hartanya segera akan dibagi-bagi, meskipun hal ini tidak berarti bahwa bisnis dari perusahaan pailit tersebut tidak bisa dilanjutkan. Dalam UU No 37 Tahun 2004 tentang Kepilitan dan Penundaan Kewajiban Pembayaran Utang tidak ada ketentuan yang menyebutkan bahwa Insolvency Test merupakan syarat untuk mempailitkan debitor/ perusahaan. ${ }^{3}$ Tidak adanya pengaturan mengenai Insolvency Test tersebut tentu saja dapat menimbulkan masalah bagi perusahaan seperti misalnya Perseroan Terbatas (PT), sehingga menyebabkan banyak perusahaan-perusahaan di Indonesia yang mengalami kebangkrutan secara hukum.

\subsection{Rumusan Masalah}

1. Bagaimana urgency/pentingnya insolvency test dalam penetapan pailit pada Perusahaan/ Perseroan Terbatas (PT) ?

2 Munir fuady, 1999,Hukum Pailit dalam Teori dan Praktek, Citra Aditya Bakti, Bandung, hal 135.

${ }^{3}$ Sutan Remi Sjahdeini, 2016, Sejarah, Asas dan Teori Hukum Kepailitan, Edisi 2, Prednada Media, Jakarta, h.129. 
2. Bagaimana akibat hukum apabila Perusahaan/ Perseroan Terbatas (PT) dimohonkan insolvency test sebelum dinyatakan pailit?

\subsection{Tujuan Penulisan}

1. Untuk mengetahui urgency/pentingnya insolvency test dalam penetapan pailit pada Perusahaan/ Perseroan Terbatas (PT).

2. Untuk mengetahui bagaimana Akibat hukum apabila Perusahaan/ Perseroan Terbatas (PT) dimohonkan insolvency test sebelum dinyatakan pailit.

\section{ISI MAKALAH}

\subsection{Metode Penelitian}

Metode penulisan yang digunakan dalam karya ilmiah ini adalah metode penelitian hukum normatif. Dimana pemilihan metode ini sesuai yang ditulis oleh Peter Mahmud Marzuki, ${ }^{4}$ dikarenakan bahwa penelitian hukum adalah suatu proses untuk menemukan aturan hukum, prinsip-prinsip hukum, maupun doktrin-doktrin hukum guna menjawab isu hukum yang dibahas.

\subsection{HASIL DAN PEMBAHASAN}

2.2.1 Urgency atau Pentingnya Insolvency Test dalam Penjatuhan Putusan Pailit Pada Perusahaan

Utang dalam kepailitan merupakan kewajiban dari suatu debitor di bidang bisnis setidaknya menyangkut mengenai prihal harta benda dengan berlandaskan kepada ketidakmampuan debitor

\footnotetext{
${ }^{4}$ Peter Mahmud Marzuki, 2005, Penelitian Hukum, Prenada Media, Jakarta, hal 35.
} 
untuk membayar kewajibannya. ${ }^{5}$ Dalam UU No 37 Tahun 2004 Tentang Kepilitan dan Penundaan Kewajiban Pembayaran Utang (PKPU), menyebutkan bahwa "ketidakmampuan untuk membayar"itu disebut juga sebagai Insolvency. Menurut M Hadi Subhan Insolvency Test merupakan uji kemampuan debitor dalam rangka pembayaran utang-utangnya yang mencakup uji arus kas perusahaan dan uji neraca perusahaan. Insolvency Test itu sendiri belum diterapkan ataupun diatur di Indonesia namun, di beberapa negara penerapan Insolvency Test sudah berlaku dan dianggap penting dalam menentukan penjatuhan pailit kepada suatu perusahaan.UndangUndang Kepailitan yang berlaku sekarang dirasa masih belum mengakomodir asas perlindungan hukum yang berimbang khususnya dalam memberikan perlindungan hukum terhadap debitor. ${ }^{6}$ Seperti Di Amerika Serikat, di negara ini sudah megalami perkembangan hukum kepailitan yang sangat pesat walaupun bentuk sistem hukumnnya adalah common law. Negara Common Law sering menjadi acuan dalam pembuatan Undang-Undang, tanpa terkecuali Undang-Undang tentang kepailitan atau yang disebut dengan Bankrupty Reform Act Of 1978 atau Bankruptcy Code. Didalam Undang-Undang tersebut telah mengatur mengenai Insolvency Test. Dimana di Amerika Serikat pengaturan mengenai Insolvency Test dinggap penting untuk menentukan apakah suatu

5 I Wayan Wesna Astara,2015,"Penundaan Kewajiban Pembayaran Utang Dalam Kepailitan (Analisis Terhadap Putusan Pengadilan Niaga Nomor: 20/Pailit/2011/ Pn.Niaga.Sby)",Jurnal Hukum Magister Ilmu Hukum dan Kenotariatan, Fakultas Hukum Universitas Udayana, Denpasar, hal 409. Diakses Tanggal 22 Mei 2019.

6 Gedalya Iryawan Kale,2018, "Syarat Kepailitan Sebagai Bentuk Perlindungan Hukum Debitor Dalam Undang-Undang Nomor 37 Tahun 2004”, Vol. 06, No. 03, Mei 2018, May, 2018, Fakultas Hukum Universitas Udayana,Denpasar,hal 7. Ojs.unud.ac.id, URL : https://ojs.unud.ac.id/index.php/ kerthasemaya/ article/view/40730 diakses tanggal 29 April 2019 jam 21.20. 
perusahaan berbadan hukum atau debitor dianggap solven atau tidak. Dalam Undang-Undang tersebut, Uniform Fradulent Transfer Act (UFTA), berusaha memberi solusi mengenai adanya insolvensi test yang dapat diterapkan dalam hal membuktikan debitor yang telah insolven untuk dimohonkan dan diputuskan pailit.

Secara Universal terdapat 3 finansial tes untuk menentukan insolvensi dalam kepailitan dan hukum perusahaan, yaitu:

1. To ability to pay solvency test atau dikenal dengan cash flow solvency test atau equitable solvency test yang dapat dikatakan test untuk menentukan apakah suatu debitor (perusahaan) dapat membayar utangnya ketika telah jatuh waktu.

2. The balance sheet solvency test yang dapat dikatakan sebagai test yang menentukan apakah nilai aset yang wajar dari suatu debitor dapat menutupi dari kewajibannyan (utang).

3. The capital adequany solvency test atau dikenal juga dengan analisis transaksional yang dapat dikatakan sebagai tesy yang menentukan apakah perusahaan memiliki kapital yang memadai. ${ }^{7}$

sehingga dapat dikatakan insolvency Test tersebut sebenarnya penting dalam menentukan apakah seorang debitor atau perusahaan berbadaan hukum seperti Perseroan Terabatas (PT) yang dalam keadaan insolvensi dapat dinyatakan pailit. Selain itu untuk mengetahui peluang yang dimiliki debitor salah satunya dapat dilihat dari keadaan keuangan debitornya, namun dalam UUK PKPU tidak mengatur sama sekali tentang kondis debitor yang digunakan sebagai syarat dijatuhkannya pailit. Seharusnya dalam hal ini Lembaga Kepailitan digunakan sebagai upaya terakhir (Ultimum Remedium) dalam melunaskan utang-utang yang sudah tidak sanggup dilunasi

\footnotetext{
${ }^{7}$ Nancy A Petterman and Herri Morissete, 2004, Directors Duties in the zone of insolvency: The Quandary of the non-Profit 23 AM Bankr, Inst 12.
} 
oleh debitor. ${ }^{8}$ Sehingga, sebelum Lembaga Kepailitan digunakan untuk penjatuhan pailit terhadap Perusahaan berbdaan hukum seperti misalnya Perseroan Terabatas (PT) dapat memohonkan insolvency test sebelum perusahaan itu benar-benar dinyatakan pailit. Maka dari itu, sebenarnya pengaturan mengenai Insolvency Test tersebut sangat penting untuk di terapkan di Indonesia, sehingga tidak menyebabkan perusahaan yang masih di anggap solven atau masih mampu membayar utang-utangnya dinyatakan pailit atau bangkrut secara hukum oleh Lembaga Kepailitan.

\subsubsection{Akibat Hukum dari Adanya Insolvency Test Terhadap Perusahaan yang Dimohonkan Pailit}

Insolven secara umum merupakan keadaan suatu perusahaan yang kondisi aktivannya lebih kecil dari pada pasivanya dengan kata lain utang perusahaan lebih besar dari pada harta perusahaan. ${ }^{9}$ jika hal ini terjadi disebut sebagai technical insolvency. Pada dasarnya sebelum pernyataan pailit, hak-hak debitur untuk melakukan semua tindakan hukum berkenaan dengan kekayaannya harus dihormati. Tentunya dengan memperhatikan hak-hak kontraktual serta kewajiban debitur menurut peraturan perundang-undangan. ${ }^{10}$

${ }^{8}$ Adi Nugroho Setiarso,2013,Analisis Yuridis Terhadap Keadaan Insolvensi Dalam Kepailitan (Study Nomatif Pasal 2 Ayat 1 Undang-undang Nomer 37 tahun 2004 tentang Kepailitan dan Penundaan Kewajiban Pembayaran Utang), Fakultas Hukum Universitas Brawijaya, Malang, hal. 12.

9 M. Hadi Subhan, 2014, Hukum Kepailitan: Prinsip, Norma, dan Praktik Peradilan, Pustaka Grafika, Jakarta, h.144.

${ }_{10}$ R. Soemitro, 1993, Hukum Perseroan Terbatas, Yayasan Dan Wakaf, PT Eresco, Bandung, hal. 89 
Di Indonesia, Undang-Undang Kepailitan dan PKPU tidak mensyaratkan atau mengatur agar keadaan insolven menjadi suatu syarat Perseroan Terbatas dapat diputuskan pailit melainkan hanya mengacu dalam Pasal 2 ayat (1) Undang-Undang Nomor 37 Tahun 2004 tentang Kepailitan dan PKPU. Hal tersebut menyebabkan banyak Perseroan terbatas di Indonesia dinyatakan pailit oleh Pengadilan Niaga, padahal kenyataannya perusahaan tersebut masih tergolong sebagai Perseroan Terbatas yang solven dan jumlah asetnya jauh diatas jumlah utang-utangnya dikarenakan tidak diterapkannya insolvency test tersebut.

Pengaturan mengenai kepailitan di Indonesia sangat berbeda dengan syarat kepailitan di negara lain seperti Amerika Serikat dan Belanda. Sebagai contoh negara Amerika Serikat menerapkan insolvency Test dalam hal mengajukan permohonan pailit atas suatu badan hukum dengan tujuan untuk menentukan solvabilitas keuangan suatu badan hukum untuk selanjutnya ditentukan apakah sudah layak untuk dipailitkan atau tidak. Insolvency Test tersebut dilakukan dengan menggunakan beberapa metode perhitungan misalnya cash flow test untuk menyatakan debitur tersebut solven 
atau tidak. ${ }^{11}$ Kemudian, negara Belanda dalam Undang-Undang Kepailitannya mengatur syarat kepailitan suatu badan hukum dalam Dutch Bankcrupty Act dimana seorang debitur dapat mengajukan atau dapat diajukan di muka pengadilan apabila debitur tersebut sudah dalam keadaan berhenti membayar utangnya. Meskipun syarat di dalam Dutch Bankcrupty Act hanya mengatur syarat mengenai keadaan berhenti membayar utang, namun dalam penjelasannya bahwa kreditor di dalam persidangan harus benarbenar membuktikan bahwa debitur sudah tidak mampu lagi untuk melanjutkan untuk membayar utangnya atau dalam keadaan insolven. ${ }^{12}$

Syarat kepailitan di Negara Amerika Serikat dan Belanda tersebut menunjukan bahwa negara tersebut memiliki syarat insolvensi untuk pengajuan permohonan pailit sehingga persyaratan Insolvency Test dapat berakibat hukum apabila debitur yang diajukan ke muka pengadilan oleh kreditur untuk dipailitkan terbukti dalam keadaan solven maka debitur tersebut tidaklah dapat diajukan atau mengajukan ke pengadilan untuk dipailitkan dikarenakan keadaan

11 Munir Fuady, 1999, Hukum Pailit dalam Teori dan Praktek, PT. Citra Aditya Bakti, Bandung, h.129.

12 Dewi Rusmy Mustari, Teddy Anggoro, Myra R. Budi Setiawan, 2013, Tinjauan Yuridis Insolvensi Sebagai Syarat Kepailitan (Studi Kasus Kepailitan PT. Telekomunikasi Selular dan PT. Asuransi Jiwa Manulife Indonesia, Jurnal Fakultas Hukum, Universitas Indonesia, Depok, h.18. 
debitur yang masih sanggup untuk membayar utang-utang krediturnya, sebagai alternatif, kreditur dapat menempuh gugatan perdata biasa agar debitur yang dalam hal ini Perseroan Terbatas mau memenuhi kewajibannya.

Penting pula diketahui akibat hukum Insolvency terhadap suatu Perseroan Terbatas (PT) yang dinyatakan pailit, untuk itu harus dilihat dahulu apakah Perseroan Terbatas tersebut sebagai debitor pailit atau kreditur yang mengajukan permohonan pailit ke Pengadilan Niaga. Apabila yang mengalami insolvency tersebut adalah Perseroan Terbatas yang sudah Go Public maka, akibat hukum yang terjadi adalah:

1. Terkena kewajiban pelaporan kepada Bapepam dan mengumumkan kepada publik tentang adanya permohonan pailit tersebut.

2. Sebelum pelaporan dilakukan, pihak yang mengetahui adanya informasi tentang kepailitan terkena peraturan ketentuan tentang Insideritrading.

3. Terkena ketentuan tentang suspense dan delisting dari bursa efek dimana saham diperjualbelikan, sesuai dengan ketentuan bursa yang bersangkutan. ${ }^{13}$

Sedangkan dengan Undang-Undang Nomor 37 Tahun 2004 tentang Kepailitan dan PKPU yang saat ini diberlakukan di Indonesia yang belum mengatur mengenai syarat insolvensi untuk mengajukan permohonan kepailitan atau terjadi kekosongan norma hukum

${ }^{13}$ Op.cit, hal 132. 
(vacuum of norm) yang memberi kesempatan bagi kreditur yang beritikad tidak baik untuk mepailitkan debitur yang masih memiliki keadaan keuangan yang solven.

\section{PENUTUP}

\subsection{KESIMPULAN}

1. Undang-Undang No 37 Tahun 2004 Tentang Kepailitan dan Penundaan Kewajiban Pembayaran Utang (PKPU) hanya mengatur mengenai insolvency namun tidak mengatur lebih lanjut mengenai Insolvency Test. Jika dilihat di Amerika Serikat diberlakukannya insolvency Test merupakan cara yang sangat mudah untuk menentukan apakah perusahaan yang dalam keadaan pailit dapat dikatakan solven atau tidak. Namun di Indonesia belum di aturnya insolvency test tersebut dalam UUK PKPU sebagai salah satu syarat dalam penjatuhan pailit bagi debitor atau Perseroan Terbatas (PT) menyebabkan banyak perusahaan-perusahaan di Indonesia yang masih dalam keadaan solven atau mampu membayar dinyatakan pailit dan bangkrut secara hukum oleh Pengadilan Niaga. Pengaturan mengenai kepailitan di Indonesia sangat berbeda dengan syarat kepailitan di negara lain seperti Amerika Serikat dan Belanda. di Negara Amerika Serikat dan Belanda tersebut menunjukan bahwa negara tersebut memiliki syarat insolvensi untuk pengajuan permohonan pailit sehingga persyaratan Insolvency Test dapat berakibat hukum apabila debitur yang diajukan ke muka pengadilan oleh kreditur untuk dipailitkan terbukti dalam keadaan solven maka debitur tersebut tidaklah dapat diajukan ke pengadilan untuk 
dipailitkan dikarenakan keadaan debitur yang masih sanggup untuk membayar utang-utang krediturnya.

\subsection{SARAN}

Akan lebih baik jika dalam UU No.37 Tahun 2004 tentang UUK dan PKPU dapat pula mengatur dan menerapkan mengenai Insolvency Test ini seperti negara-negara lain contohnya Amerika Serikat dan Belanda. Namun pada kenyataannya di Indonesia beluma ada sama sekali pengaturan mengenai Insolvency Test tersebut, sehingga banyak perusahaan-perusahaan seperti misalnya Perseron Terbatas (PT) yang masih dalam keadaan solven atau mampu membayar utang-utangnya telah dinyatakan pailit atau bangkrut secara hukum terlebih dahulu oleh Pengadilan Niaga.Selain itu seharusnya dalam UU No 37 Tahun 2004 juga lebih mengatur dan melihat kepentingan para debitor atau Perseroan Terbatas (PT) yang masih dalam keadaan solven atau tidak, Padahal dengan keadaan ekonomi Indonesia pada saat ini apabila persyaratan insolvency diterapkan maka akan sulit untuk Perseroan Terbatas (PT) dikatakan pailit.

\section{BUKU}

\section{DAFTAR PUSTAKA}

Munir fuady, 1999, Hukum Pailit dalam Teori dan Praktek, Citra Aditya Bakti, Bandung.

M. Hadi Subhan, 2009, Hukum Kepailitan : Prinsip, Norma, \& Praktik di Peradilan, Kencana, Jakarta.

M. Hadi Subhan, 2014, Hukum Kepailitan: Prinsip, Norma, dan Praktik Peradilan, Pustaka Grafika, Jakarta. 
Nancy A Petterman, dkk, 2004, Directors Duties in the zone of insolvency: The Quandary of the non-Profit Corp 23 AM Bankr, Inst.12.

Peter Mahmud Marzuki, 2005, Penelitian Hukum, Prenada Media, Jakarta.

R Soemitro, 1993, Hukum Perseroan Terbatas, Yayasan Dan Wakaf, PT Eresco, Bandung.

Sutan Remi Sjahdeini, 2016, Sejarah, Asas dan Teori Hukum Kepailitan, Edisi 2, Prednada Media, Jakarta.

\section{JURNAL ILMIAH}

I Wayan Wesna Astara, 2015, "Penundaan Kewajiban Pembayaran Utang Dalam Kepailitan (Analisis Terhadap Putusan Pengadilan Niaga Nomor: 20/Pailit/2011/Pn.Niaga.Sby)", Jurnal Hukum Magister Ilmu Hukum dan Kenotariatan, Fakultas Hukum Universitas Udayana, Denpasar.

Gedalya Iryawan Kale, 2018, "Syarat Kepailitan Sebagai Bentuk Perlindungan Hukum Debitor Dalam Undang-Undang Nomor 37 Tahun 2004,"Vol. 06, No. 03, Mei 2018, May, 2018, Fakultas Hukum Universitas Udayana ,Denpasar ,hal 7. Ojs.unud.ac.id, URL : https://ojs.unud.ac.id/index.php/kerthasemaya/ article/view/40730 diakses tanggal 29 April 2019 jam 21.20.

Dewi Rusmy Mustari,Teddy Anggoro, Myra R. Budi Setiawan, 2013, Tinjauan Yuridis Insolvensi Sebagai Syarat Kepailitan (Studi Kasus Kepailitan PT. Telekomunikasi Selular dan PT. Asuransi Jiwa Manulife Indonesia, Jurnal Fakultas Hukum, Universitas Indonesia, Depok

Adi Nugroho Setiarso, 2013, Analisis Yuridis Terhadap Keadaan Insolvensi dalam Kepailitan ( Study Nomatif Pasal 2 Ayat 1 Undangundang Nomer 37 tahun 2004 tentang Kepailitan dan Penundaan Kewajiban Pembayaran Utang), Fakultas Hukum Universitas Brawijaya, Malang. 


\section{PERUNDANG-UNDANGAN}

Bankrupty Reform Act Of 1978 atau Bankruptcy Code

Dutch Bankcrupty Act

Undang-undang Nomer 37 Tahun 2004 Tentang Kepilitan dan Penundaan Kewajiban Pembayaran Utang (Lembar Negara Republik Indonesia Tahun 2004 Nomor 131). 